\title{
Oxidation of DNA Bases by Tumor Promoter-Activated Processes
}

\section{by Krystyna Frenkel*}

\begin{abstract}
Evidence has accumulated showing that active oxygen species participate in at least one stage of tumor promotion. Tumor promoters can induce various types of cells to undergo processes that result in formation of active oxygen species. They stimulate polymorphonuclear leukocytes (PMNs) to undergo an oxidative burst that is characterized by rapid formation of ${ }^{-} \mathrm{O}_{2}^{-}$and $\mathrm{H}_{2} \mathrm{O}_{2}$. We find that in vitro formation of $\mathrm{H}_{2} \mathrm{O}_{2}$ by tumor promoter-activated $\mathrm{PMNs}$ correlates with their in vivo first-stage promoting activity. Moreover, two thymidine derivatives are formed in DNA coincubated with tumor promoter-stimulated PMNs: 5-hydroxymethyl-2'-deoxyuridine (HMdU) and thymidine glycol (dTG). The amounts of HMdU and dTG formed correlate with the first-stage tumor-promoting potencies of the agents used for PMN stimulation and with the amount of $\mathrm{H}_{2} \mathrm{O}_{2}$ generated. We find that $\mathrm{HMdU}$ is also formed in the DNA of HeLa cells coincubated with 12-O-tetradecanoylphorbol-13-acetate (TPA)-activated PMNs, with the amount of HMdU being proportional to that of TPA used. Even in the absence of PMNs, HMdU is increasingly formed in cellular DNA with increased TPA concentration, although at much lower levels than in the presence of PMNs: When rat liver microsomes are incubated with benzo[a]pyrene (BaP), a complete carcinogen, $\mathrm{H}_{2} \mathrm{O}_{2}$ is also generated. Production of $\mathrm{H}_{2} \mathrm{O}_{2}$ increases linearly with increasing concentrations of BaP. Furthermore, HMdU is formed in DNA exposed to BaP-treated microsomes, and its formation is inhibited by catalase. These results suggest that carcinogen-induced processes generating $\mathrm{H}_{2} \mathrm{O}_{2}$ are associated with the first-stage promoting activity of complete carcinogens.
\end{abstract}

\section{Introduction}

It has been well established that the tumor-initiating properties of carcinogens correlate with the formation of certain types of adducts with DNA bases (1-5). However, the mechanism of tumor promotion is not as yet clearly understood. In the last decade, a hypothesis of the multistage process of promotion proposed by Boutwell (6) has received experimental support. As of now, there seem to be two recognizable stages of promotion followed by progression from papillomas to the malignant tumors $(7-12)$.

It has been assumed for many years that modification of the genetic material occurs only at the initiation stage. However, more recent evidence shows that if the so-called first-stage promoters are applied either after, or even before, an initiating agent and used in small enough amounts so as not to cause formation of tumors, tumor growth can be induced by application of the second-stage promoters weeks later $(9,11)$. These findings suggest that the firststage promotional processes involve heritable DNA modification. This raises a number of questions: What type or types of DNA modification may constitute the

\footnotetext{
*Department of Environmental Medicine and Pathology, New York
} University Medical Center, 550 First Avenue, New York, NY 10016. first-stage promotional event(s)? What processes result in the formation of those modifications? An analysis of recent publications shows that tumor promoters induce cellular changes that lead to DNA damage and that active oxygen species generated as intermediates are responsible for this damage (13-19).

\section{Activation of Polymorphonuclear Leukocytes}

It is quite well known that polymorphonuclear leukocytes (PMNs) can be activated by tumor promoters and that such activation leads to formation of large amounts of active oxygen species in a process that is often referred to as an oxidative burst (20-23). A normal function of PMNs, cells which take part in the inflammatory and immune responses, is to recognize, phagocytize, and destroy foreign objects such as bacteria and other opsonized particles. When these cells are activated by nonphagocytic stimuli such as tumor promoters, large amounts of generated active oxygen species are free to interact with the neighboring cells and impart their damaging effects on the cellular macromolecules, including DNA. Regardless of the type of stimuli used, the elicited burst is characterized by a rapid consumption of oxygen followed by the almost concomitant production of superoxide anion radicals 
$\left(\cdot \mathrm{O}_{2}\right)(23-25)$. These radicals can dismutate both spontaneously and enzymatically to hydrogen peroxide $\left(\mathrm{H}_{2} \mathrm{O}_{2}\right)$, which is the immediate precursor of the actual bacteriocidal species that include hydroxyl radicals $(\cdot \mathrm{OH})$, hypochlorite ions, and singlet oxygen (Fig. 1) (23-26). $\mathrm{H}_{2} \mathrm{O}_{2}$ is the only one of the active oxygen species generated that is capable of easily crossing cellular membranes and of getting into the nucleus $(23,27)$. Other species need either the presence of anion channels or are too reactive to migrate through the membranes.

It has been known for some time that active oxygen species generated by phagocytic cells, both PMNs and macrophages, induce formation of DNA strand breaks in coincubated cells $(13,14)$. Formation of these strand breaks could be prevented by catalase, which points to $\mathrm{H}_{2} \mathrm{O}_{2}$ as the oxygen species responsible for this type of DNA damage. Because $\mathrm{H}_{2} \mathrm{O}_{2}$ by itself cannot interact with DNA, another species derived from it must be the ultimate damaging agent $(27,28)$. It was shown that sister chromatid exchanges induced by $\mathrm{H}_{2} \mathrm{O}_{2}$ can be prevented by using $o$-phenanthroline, an iron chelator, which is capable of crossing cellular membranles (29). This finding proves that it is a transition metal ion-induced decomposition product of $\mathrm{H}_{2} \mathrm{O}_{2}$ that is responsible for DNA breaks. The most likely candidate for the ultimate damaging agent is $\cdot \mathrm{OH}$, which is known to be formed from $\mathrm{H}_{2} \mathrm{O}_{2}$ by $\mathrm{Fe}^{2+}$ $(26,30,31)$. Metal ions do not exist in a free state in cells except in some diseases $(30,31)$. Metal ions are present as metalloproteins and are chelated to certain amino acids such as histidine or to phosphate groups of DNA. Thus, when $\mathrm{H}_{2} \mathrm{O}_{2}$ migrates into the nucleus, it may be reduced in situ to $\cdot \mathrm{OH}$ by metal ions chelated to DNA or proteins of chromatin. DNA breaks caused by this type of interaction are termed site specific. Although it seems that - $\mathrm{OH}$ or $\cdot \mathrm{OH}$-like species is ultimately responsible for the DNA damage, it is $\mathrm{H}_{2} \mathrm{O}_{2}$ that is stable and unreactive enough to travel into the nucleus that initiates the damag. ing process. For this reason, this laboratory has examined in some detail formation of $\mathrm{H}_{2} \mathrm{O}_{2}$ by PMNs.

\section{Formation of $\mathrm{H}_{2} \mathrm{O}_{2}$ by Tumor Promoter-Activated PMNs}

It has been known for some time that tumor promoters of the phorbol ester type such as 12-O-tetradecanoylphorbol-13-acetate (TPA), mezerein (Mez), and teleocidins can stimulate PMNs (12,22). Recently, non-TPA type tumor promoters such as palytoxin and thapsigargin were shown to activate phagocytic cells as well (32). This suggests that induction of the oxidative burst in phagocytes may be common among tumor promoters. Mez, a potent

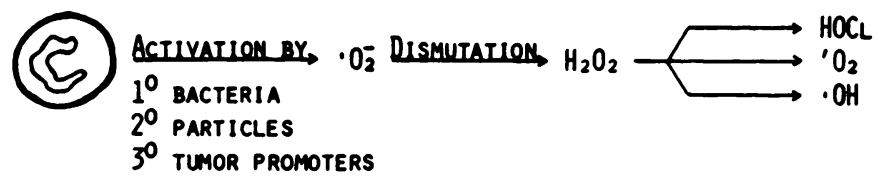

FIGURE 1. Generation of active oxygen species by PMNs. second-stage promoter and a first-stage promoter weaker than TPA (12), caused formation of $\cdot \mathrm{O}^{\overline{2}}$ at levels that were comparable to those induced by TPA (33). These results led to a conclusion that formation of active oxygen species by PMNs stimulated with tumor promoters does not correlate with the first-stage promotion. This laboratory has postulated that it is $\mathrm{H}_{2} \mathrm{O}_{2}$, an immediate precursor of the DNA damaging species $\cdot \mathrm{OH}$, and not $\cdot \mathrm{O}_{2}$, that correlates with the first-stage activity (34). It is known that, depending on the stimuli, varying percentages of generated $\cdot \mathrm{O}_{2}^{-}$dismutate to $\mathrm{H}_{2} \mathrm{O}_{2}(21,35)$ and, therefore, formation of $\cdot \mathrm{O}_{2}$ does not have a predictive value as to how much $\mathrm{H}_{2} \mathrm{O}_{2}$ (and ultimately $\cdot \mathrm{OH}$ ) is produced.

\section{In the Absence of Plasma}

In order to determine whether this hypothesis is correct, three tumor promoters were used (34): TPA, a complete tumor promoter with a potent first-stage activity (8,12); Mez; and 12-O-retinoylphorbol-13-acetate (RPA). RPA is a predominantly second-stage promoter with a weak first-stage activity (8), except in SENCAR mice where it is quite potent as the first-stage promoter (36). As shown in Figure 2, all three tumor promoters cause formation of increasing amounts of $\mathrm{H}_{2} \mathrm{O}_{2}$ as a function of tumor promoter when incubated with human PMNs at $37^{\circ} \mathrm{C}$ for $30 \mathrm{~min}$. Only $2.5 \mathrm{nM}$ TPA is required to achieve maximal activation of $\mathrm{PMNs}\left(10 \mu \mathrm{M} \mathrm{H}_{2} \mathrm{O}_{2}\right)$, whereas $5 \mathrm{nM}$ Mez and 15 nM RPA are needed to obtain maximal levels of $\mathrm{H}_{2} \mathrm{O}_{2}(9.1 \mu \mathrm{M}$ and $8.9 \mu \mathrm{M}$, respectively), which are lower than that caused by $2.5 \mathrm{nM}$ TPA. TPA-activated PMNs produce up to 4 and 10 times more $\mathrm{H}_{2} \mathrm{O}_{2}$ than those activated by Mez and RPA, respectively, when used at concentrations between $0.5 \mathrm{nM}$ and $15 \mathrm{nM}$ to stimulate $7.5-8.5 \times 10^{4} \mathrm{PMNs} / \mathrm{mL}$. These differences are highly significant with $p \leq 0.001$ (normal distribution $z$-test) at all data points except one. When PMNs are incubated with tumor promoters for time periods between 10 and $60 \mathrm{~min}$ at a concentration that causes maximal formation of $\mathrm{H}_{2} \mathrm{O}_{2}$,

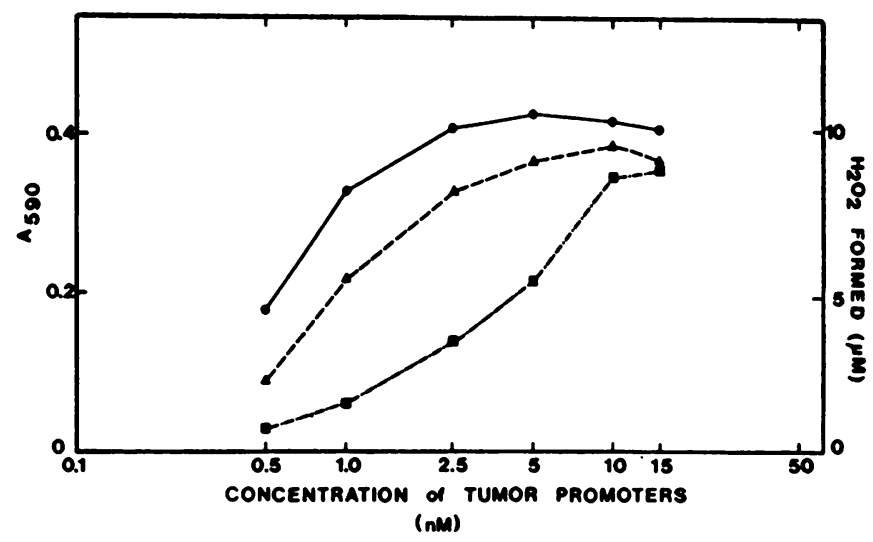

FIgURE 2. Formation of $\mathrm{H}_{2} \mathrm{O}_{2}$ by PMNs $\left(1 \times 10^{5} / \mathrm{mL}\right)$ activated with

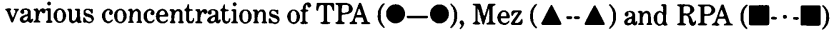
and incubated at $37^{\circ} \mathrm{C}$ for $30 \mathrm{~min}$. Left abscissa: absorbance at 590 $\mathrm{nm}$. Right abscissa: concentration of $\mathrm{H}_{2} \mathrm{O}_{2}$ as read from a standard curve. Reprinted from Frenkel and Chrzan (34). 
this difference between promoters is even more apparent, as shown in Figure 3A. Thus, it is quite evident that TPA is the most active and RPA the least, whereas phorbol, a nonpromoting parent of TPA, is totally inactive in this assay. These findings show that formation of $\mathrm{H}_{2} \mathrm{O}_{2}$ by activated PMNs correlates with the in vivo first-stage tumor promoting potency of the agents used for that activation.

\section{In the Presence of Plasma}

Since a normal biological milieu of PMNs is serum, the same type of experiments were carried out in the presence of $10 \%$ autologous plasma containing all of the components of the blood except for the red and white blood cells (36). As Figure $3 B$ shows, the accumulation of $\mathrm{H}_{2} \mathrm{O}_{2}$ decreases significantly in the presence of plasma in the case of all three tumor promoters that were used. It is not known what causes that decrease. It could be an inhibition of $\mathrm{H}_{2} \mathrm{O}_{2}$ formation, as plasma contains some protease inhibitors, and we found that chymotrypsin-specific inhibitors decrease $\mathrm{H}_{2} \mathrm{O}_{2}$ formation by TPA-activated PMNs (37). Such decrease in the accumulation of $\mathrm{H}_{2} \mathrm{O}_{2}$ could also occur when $\mathrm{H}_{2} \mathrm{O}_{2}$ interacts with some Fe-containing proteins. Catalase is present only in small amounts in serum and, therefore, should not have much influence. However, there are peroxidases $(22,38,39)$ that may catalyze oxidation of certain components of serum, and such an occurrence could compete with the horseradish peroxidasemediated oxidation of phenol red, on which our assay is based.

Whatever the reason or combination of reasons for the decrease in the accumulation of $\mathrm{H}_{2} \mathrm{O}_{2}$, that inhibition occurs regardless of which tumor promoter is used for the activation of PMNs. However, the degree of that inhibition differs, being the highest for RPA, followed by Mez, and lowest for TPA. This is most apparent at $10 \mathrm{~min}$ incubation time in the presence of plasma at which there is no detectable $\mathrm{H}_{2} \mathrm{O}_{2}$ in the case of RPA as the PMN activator (Fig. $3 B$ ), whereas there is $1.6 \mu \mathrm{M} \mathrm{H}_{2} \mathrm{O}_{2}$ formed in the absence of plasma (Fig. $3 A$ ). Mez-activated PMNs decrease production of $\mathrm{H}_{2} \mathrm{O}_{2} 20$-fold in the presence of plasma; TPA-activated cells decrease production by only 10 -fold. At 20 min incubation time, the effect of plasma is smaller, but there is 6-fold inhibition in the case of RPA, 5.5 with $\mathrm{Mez}$, and 4 with TPA. At 30 min incubation, that decrease is 6-, 3-, and 2-fold for RPA, Mez, and TPA, respectively.

The differences in the degree of inhibition would favor the hypothesis that it is the inhibition of $\mathrm{H}_{2} \mathrm{O}_{2}$ formation by some plasma components which plays a major role in the apparent decrease in $\mathrm{H}_{2} \mathrm{O}_{2}$ accumulation. Tumor promoters would have to overcome this inhibition, and the ability to do so may depend on the potency of those promoters. These findings show that even in the presence of plasma, the differences in the ability to activate PMNs among these tumor promoters not only remain but are even more pronounced, and that again TPA is the most effective, whereas RPA is the least effective of the three-the same order of activity as in vivo.
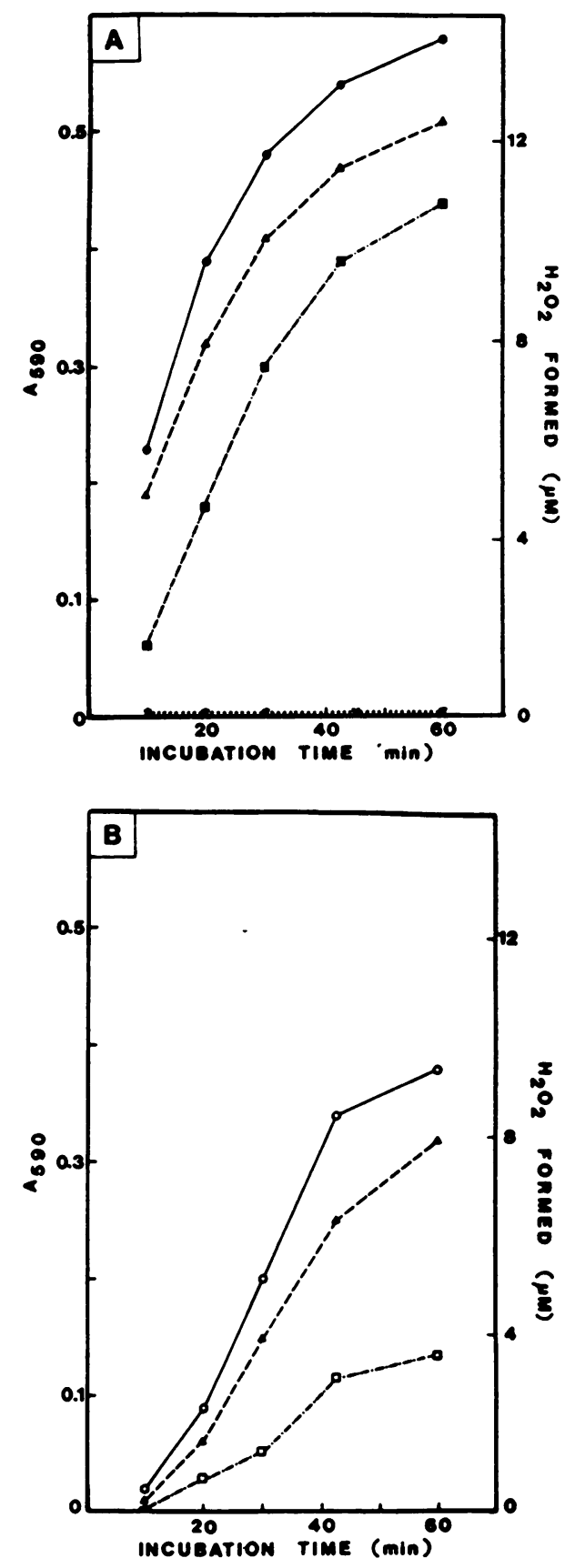

FIGURE 3. Formation of $\mathrm{H}_{2} \mathrm{O}_{2}$ by PMNs $\left(1 \times 10^{5} / \mathrm{mL}\right)$ activated with 25 $\mathrm{nM}$ agents in the absence $(A)$ and the presence $(B)$ of $10 \%$ autologous plasma and incubated at $37^{\circ} \mathrm{C}$ between 10 and $60 \mathrm{~min}$. Left abscissa: absorbance at $590 \mathrm{~nm}$. Right abscissa: concentration of $\mathrm{H}_{2} \mathrm{O}_{2}$ as read

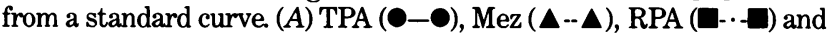
phorbol $(\times \cdots \times)$. Reprinted from Frenkel and Chrzan (34). (B) TPA

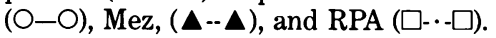

\section{Formation of Oxidized Bases in DNA Exposed to Activated PMNs}

Since the most important characteristic of the firststage tumor promoters seems to be an induction of a heritable DNA damage, we have decided to determine 
whether active oxygen species generated by tumor promoter-activated PMNs are capable of causing modification of DNA bases. To achieve this goal, DNA prelabeled with $\left[6{ }^{3} \mathrm{H}\right]$ thymidine $(40)$ was coincubated with tumor promoter-stimulated PMNs. DNA was then enzymatically digested to 2'-deoxyribonucleosides, which were analyzed by HPLC on the reverse-phase column in the presence of various thymidine derivatives as markers. These types of markers were used because thymine moiety is known to be the most susceptible of the DNA bases to the ionizing radiation-induced DNA damage $(28,41)$. Since that damage is known to be mediated through the action of $\cdot \mathrm{OH}$, it seemed likely that active oxygen species generated by the stimulated PMNs will also cause the same type of damage. Indeed, two thymidine derivatives, 5-hydroxymethyl-2'-deoxyuridine (HMdU) and thymidine glycol (dTG) (Fig. 4) were identified in DNA that was exposed to the activated PMNs $(34,42,43)$.

\section{TPA-Induced PMN Activation}

In the Absence of Plasma. As Table 1 shows, there are $9 \mathrm{HMdU}$ and $31 \mathrm{dTG}$ (sample-control) residues formed per $10^{6}$ thymidine residues in DNA coincubated with TPAstimulated PMNs. These values are greatly increased in the presence of $\mathrm{Fe}^{2+}$ ions chelated to EDTA. What is also interesting is that the time of addition of the Fe/EDTA complex to the incubation mixture influences the overall amounts of the oxidized thymidines produced. Thus, addition of the complex at the same time as TPA ( 0 time) or 10,15 , and $20 \mathrm{~min}$ after TPA, results in 5-, 13-, 30-, and 35-fold increases in HMdU formation and 6-, 7-, 6.5-, and 5 -fold increases in dTGs. These findings show that Fe ions are necessary for the formation of the ultimate damaging species. They also show that if more $\mathrm{H}_{2} \mathrm{O}_{2}$ accumulates before addition of $\mathrm{Fe} / \mathrm{EDTA}$, higher $\cdot \mathrm{OH}$ flux can be generated, which leads to an increase in the production of oxidized DNA bases, again pointing to the involvement of $\mathrm{H}_{2} \mathrm{O}_{2}$ in such a modification. The surprise finding was that although dTG is initially formed at higher levels than

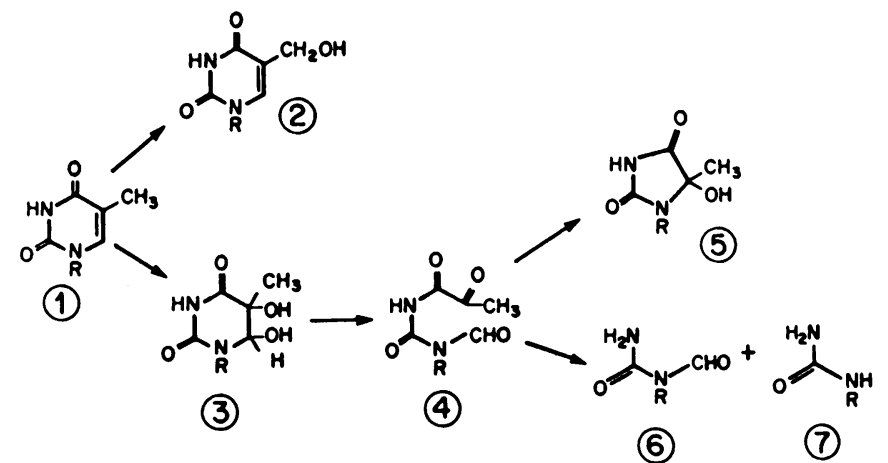

FIGURE 4. Structures of some derivatives of thymine moiety formed through the effects of radiolytically derived hydroxyl radicals; bases when $\mathrm{R}=\mathrm{H}$ and 2 '-deoxyribonucleosides when $\mathrm{R}=2$ '-deoxyribose, (1) thymine; (2) 5-hydroxymethyluracil; (3) thymine glycol; (4) $N^{\prime}$-formyl- $N$-pyruvylurea; (5) 5-hydroxy-5-methylhydantoin; (6) $N$ formylurea; (7) urea. Reprinted from Frenkel et al. (43).
$\mathrm{HMdU}$, increased amounts of generated $\cdot \mathrm{OH}$ caused a relatively small increase in dTG, followed by a decline. What we found eventually was that $\cdot \mathrm{OH}$ generated by $\mathrm{Fe}^{2+}$-reduced $\mathrm{H}_{2} \mathrm{O}_{2}$ not only causes formation of dTG but its decomposition as well, whereas HMdU is not susceptible to such decomposition (43).

In the Presence of Plasma. Another unexpected result was a great enhancement of thymine oxidation in the presence of autologous plasma. Human blood serum is known to contain free radical scavengers and antioxidants $(38,39,44)$, and therefore a decrease in DNA damage was anticipated. Instead, the results of four experiments (Table 1) show that plasma increases levels of HMdU by 65 to 1800 times. The divergence of the results is not that unexpected because the content of human serum varies even within the same individual depending on the food intake and the presence of vitamins such as A, C, and E, among other factors.

We also have found that levels of $\mathrm{H}_{2} \mathrm{O}_{2}$ generated vary, not only among individuals but also among samples of PMNs from the same individual but ohtained on different dates (34). However, the dom et of enhancement of oxidized thymines formed in DNA exposed to PMNgenerated active oxygen species in the presence of plasma is puzzling. We have established that $\mathrm{H}_{2} \mathrm{O}_{2}$ is involved in formation of that damage since catalase prevents it (unpublished data). Knowing that $\mathrm{Fe}$ is needed for the formation of $\cdot \mathrm{OH}$ from $\mathrm{H}_{2} \mathrm{O}_{2}$, we looked for the potential source of that iron and it seemed that transferrin, a ubiquitous (2-3.2 $\mathrm{mg} / \mathrm{mL}$ serum) $\mathrm{Fe}$-containing protein, may have served as a catalyst. As it turns out, Fe-loaded transferrin is capable of catalyzing formation of $\mathrm{HMdU}(43)$. Fe complexed to transferrin is approximately 25 times more effective than Fe chelated to EDTA. When DNA is exposed to active oxygen species generated by stimulated PMNs, other plasma components may modulate the catalytic effects of transferrin. In particular, other proteins, by being substrates for a nonspecific oxidation, should protect DNA. However, human albumin, which is the most abundant serum protein $(60-80 \mathrm{mg} / \mathrm{mL}$ serum $)$, does not decrease HMdU formation.

Table 1. Formation of HMdU and dTG in DNA exposed to the activated PMNs. ${ }^{a}$

\begin{tabular}{|c|c|c|c|c|}
\hline \multirow[b]{2}{*}{$\begin{array}{l}\text { Treatment } \\
\text { of PMNs }\end{array}$} & \multirow{2}{*}{$\begin{array}{c}\text { Time of } \\
\text { Fe/EDTA } \\
\text { addition after } \\
\text { TPA, min }\end{array}$} & \multicolumn{2}{|c|}{ HMdU } & \multirow[b]{2}{*}{$\begin{array}{c}\text { dTG } \\
\text { formed per } \\
10^{6} \mathrm{dT}^{\mathrm{b}} \\
\text { residues }\end{array}$} \\
\hline & & $\begin{array}{c}\text { Formed per } \\
10^{6} \mathrm{dT}^{\mathrm{b}} \\
\text { residues }\end{array}$ & $\begin{array}{c}\text { Radiation } \\
\text { equivalency, } \\
\text { Gy }\end{array}$ & \\
\hline DMSO & $-{ }^{c}$ & 7 & 0.26 & 38 \\
\hline TPA & - & 16 & 0.60 & 69 \\
\hline TPA & 0 & 50 & 1.87 & 191 \\
\hline TPA & 10 & 123 & 4.59 & 228 \\
\hline TPA & 15 & 280 & 10.45 & 207 \\
\hline TPA & 20 & 325 & 12.13 & 147 \\
\hline $\mathrm{TPA}+$ plasma & - & 650 & 24.26 & 790 \\
\hline $\mathrm{TPA}+$ plasma & - & 1,140 & 42.73 & 540 \\
\hline $\mathrm{TPA}+$ plasma & - & 8,000 & 298.6 & 0 \\
\hline TPA + plasma & - & 17,900 & 668 & 0 \\
\hline
\end{tabular}

${ }^{\mathrm{a}}$ Based on Frenkel et al. (43).

bdT, thymidine.

-, Fe/EDTA was not added. 
Presence of plasma also changes the levels of dTG in DNA. At the lowest amount of $\mathrm{HMdU}\left(65 / 10^{6}\right.$ thymidines) there was more dTG $\left(79 / 10^{6}\right)$ than HMdU, but with the increased HMdU formation, levels of dTG decreased, down to the nondetectable (Table 1). The increase in the levels of HMdU attests to the formation of $\cdot \mathrm{OH}$. Therefore, this difference in response is likely to be due to the susceptibility of dTG to the degrading effects of Fe-mediated generation of $\cdot \mathrm{OH}$ from $\mathrm{H}_{2} \mathrm{O}_{2}$, as we found to be the case in the absence of plasma. These results show that in addition to HMdU and dTG, other dTG-derived decomposition products, some of which are included in Figure 4, may be formed in such DNA. It is likely that in addition to modified thymines, other oxidized products such as 8-hydroxyguanine are also formed in DNA exposed to tumor promoter-stimulated PMNs.

Radiation equivalency values (Table 1 ), which provide a comparison between HMdU formation in DNA exposed to active oxygen species generated by TPA-stimulated PMNs and HMdU formed in DNA by ionizing radiation, show that human PMNs have a potential to cause extensive DNA damage. HMdU, which also can be incorporated into the DNA of bacterial and mammalian cells, is cytostatic and cytotoxic and possesses radiomimetic properties in that it causes diarrhea and leukopenia in mice (45-48). In addition, HMdU is mutagenic in bacterial and mammalian cells, and its mutagenic effects are comparable in many ways to those caused by ionizing radiation (49). Thus, it is likely that HMdU is among those modified bases that are responsible for the heritable effects of the first-stage tumor promoters. It is difficult to predict whether dTG may also be responsible for the heritable changes because it is known to provide a replication block $(50,51)$ and, thus, may constitute a lethal rather than a mutagenic lesion. However, since dTG gives rise to a number of the decomposition products (Fig. 4) $(52,53)$, some of them may contribute to the memory effects.

\section{Effects of Mez and RPA on Formation of HMdU and dTG}

We have found that in vitro formation of $\mathrm{H}_{2} \mathrm{O}_{2}$ by tumor promoter-activated PMNs correlates with their in vivo first-stage promoting potency, with TPA being the most effective in generating $\mathrm{H}_{2} \mathrm{O}_{2}$, followed by $\mathrm{Mez}$ and RPA (34). As TPA-stimulated PMNs cause formation of HMdU and dTG in DNA exposed to those cells, Mez- and RPAactivated PMNs should also oxidize thymine moiety but to a lesser extent than TPA. The results of those experiments show (Table 2) that when the Fe/EDTA complex is added 15 min after tumor promoters, $19 \mathrm{HMdU}$ residues (per $10^{4}$ thymidines) are formed with TPA, 14 with Mez, and 5 with RPA as activators of PMNs. At the same time, 16,7 , and $1 \mathrm{dTG}$ residues (per $10^{4}$ thymidines) are also formed with TPA, Mez, and RPA, respectively. Thus, formation of both HMdU and dTG in DNA exposed to tumor promoter-activated PMNs correlates with the first-stage potency of the activating agents. HMdU is probably the
Table 2. Number of HMdU and dTG per $10^{4}$ thymidine residues in DNA exposed to TPA-, Mez-, and RPA-activated PMNs. ${ }^{a}$

\begin{tabular}{ccc}
\hline Tumor promoter & HMdU & dTG \\
\hline- & 1 & 3 \\
TPA & 20 & 19 \\
Mez & 15 & 10 \\
RPA & 6 & 4 \\
\hline
\end{tabular}

${ }^{\mathrm{a}} \mathrm{Fe} / \mathrm{EDTA}(0.1 \mathrm{mM} / 0.4 \mathrm{mM})$ was added to human PMNs $\left(1 \times 10^{6} / \mathrm{mL}\right)$ that were pretreated with TPA, Mez, and RPA $(25 \mathrm{nM})$ at $37^{\circ} \mathrm{C}$ for $15 \mathrm{~min}$ and incubated together for an additional $45 \mathrm{~min}$. DNA was isolated and analyzed as described in the legend to Fig. 5.

more reliable marker of the two because it is not susceptible to further destructive interaction with $\cdot \mathrm{OH}$ as is dTG (43).

Because autologous human plasma has such a profound effect on the formation of oxidized thymines by TPAactivated cells, the same type of experiments were undertaken using Mez and RPA. Figure 5 shows that when the same PMN preparations are used in order to minimize the influence of the inherent variability, again, as in the case of $\mathrm{H}_{2} \mathrm{O}_{2}$ formation, TPA is the most and RPA is the least effective in the formation of HMdU and dTG. A comparison of this figure with Table 2 shows that the difference in the effectiveness of TPA and Mez in the presence of plasma is even greater than in its absence, similar to $\mathrm{H}_{2} \mathrm{O}_{2}$ formation.

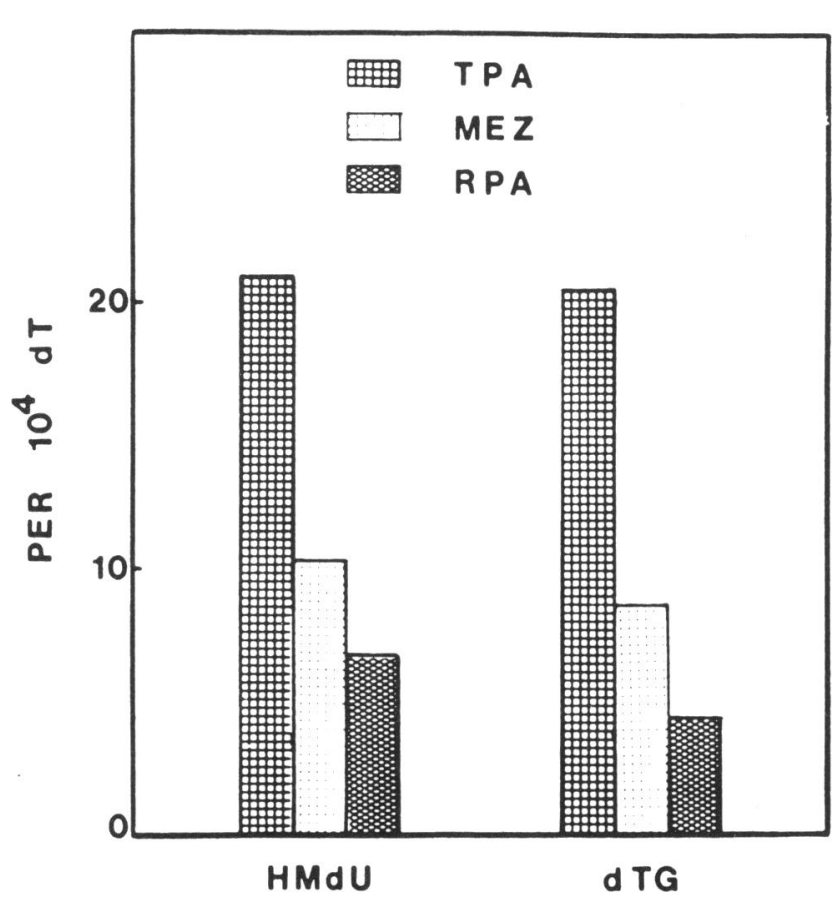

Figure 5. Formation of HMdU and dTG in $\left[{ }^{3} \mathrm{H}\right] \mathrm{DNA}(10 \mu \mathrm{g} / \mathrm{mL})$ ex posed to PMNs $\left(1 \times 10^{6} / \mathrm{mL}\right)$ that were activated with $25 \mathrm{nM}$ TPA, $\mathrm{Mez}$, and RPA in the presence of $10 \%$ autologous plasma and incubated at $37^{\circ} \mathrm{C}$ for $60 \mathrm{~min}$. DNA was purified, enzymatically digested to 2'-deoxyribonucleosides, and analyzed on the $\mathrm{C}_{18} \mathrm{HPLC}$ column in the presence of ${ }^{14} \mathrm{C}$-containing HMdU and dTG (48). Fractions coeluting with the markers were acetylated and again analyzed by HPLC. 


\section{Formation of HMdU in Cellular DNA}

Of the active oxygen species generated by stimulated PMNs, only $\mathrm{H}_{2} \mathrm{O}_{2}$ can easily cross cellular membranes $(23,27,31)$. Superoxide requires the presence of ion channels, whereas other species such as $\cdot \mathrm{OH}$ and hypochlorite are too reactive to travel far, instead, they interact with membrane constituents $(23,25,31,54)$. To determine whether exogenously produced $\mathrm{H}_{2} \mathrm{O}_{2}$ is capable of damaging the DNA of neighboring cells, we looked for the formation of HMdU in the DNA of HeLa cells coincubated with TPA-stimulated PMNs in the presence of $10 \%$ autologous plasma. Figure 6 shows that HMdU is indeed formed and that its formation is dependent on the amount of TPA used for the activation of cells. This figure also shows that a certain amount of HMdU is formed in HeLa cells incubated with TPA in the absence of PMNs. HMdU is formed in the DNA of HeLa cells in increasing amounts with the increased concentration of TPA, until TPA is too toxic to the cells, as determined by trypan blue exclusion (Fig. 7). This finding is very important because it shows that even in the absence of an exogenous source of $\mathrm{H}_{2} \mathrm{O}_{2}$ such as PMNs, tumor promoters can induce intracellular formation of active oxygen species. Such oxidative activation of cells results in the modification of DNA bases, formation of which can be enhanced by the action of stimulated phagocytic cells.

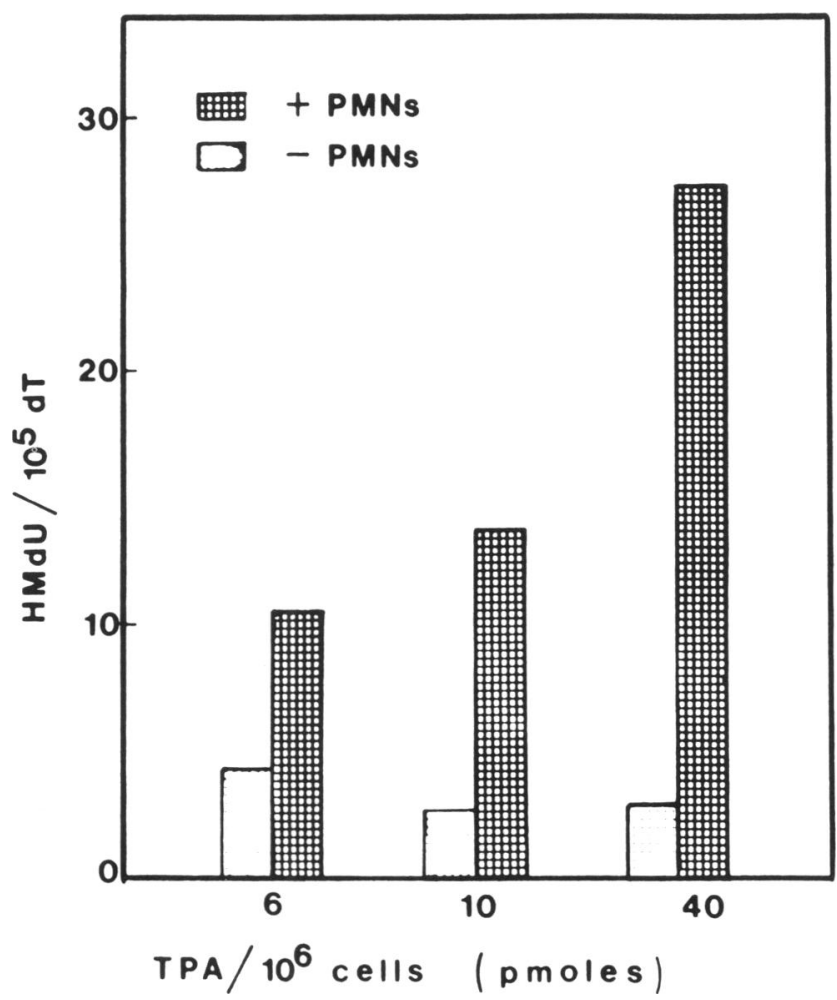

FIGURE 6. Formation of HMdU in DNA of HeLa cells prelabeled with $\left[6^{-3} \mathrm{H}\right]$ thymidine $(40)$ through the action of TPA-activated PMNs. Each sample (+PMNs) and control (-PMNs) was incubated at the same time at $37^{\circ} \mathrm{C}$ for $2 \mathrm{hr}$. DNA was isolated, enzymatically digested to 2 '-deoxyribonucleosides, and analyzed by HPLC and microderivatization (40,43). Reprinted from Frenkel and Chrzan (19).

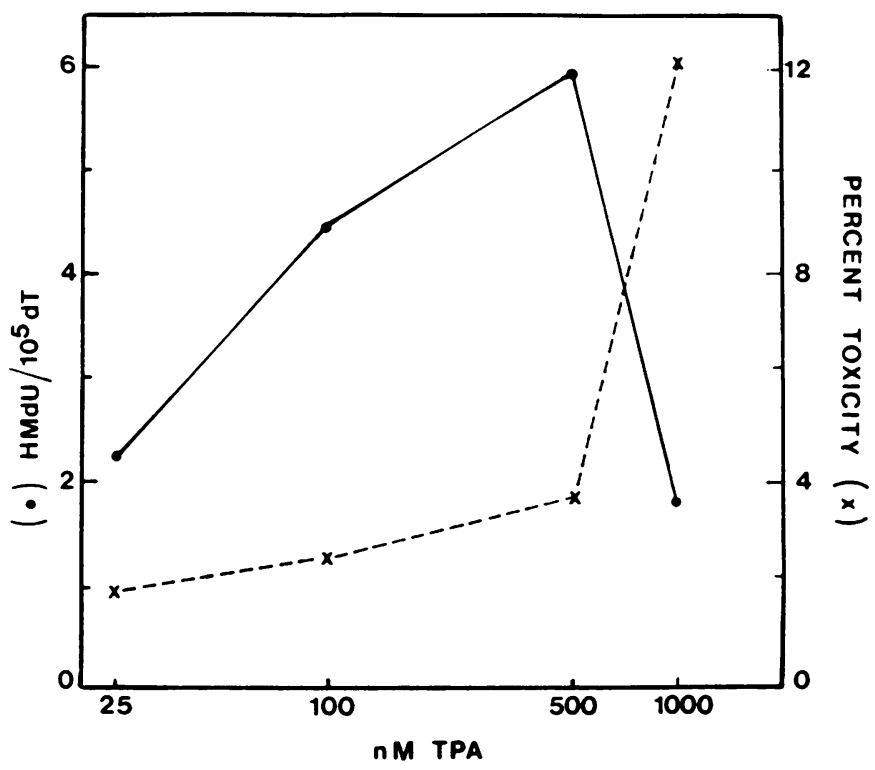

FIGURE 7. Formation of HMdU in DNA of HeLa cells $\left(1.8 \times 10^{6} / \mathrm{mL}\right)$ incubated with TPA at $37^{\circ} \mathrm{C}$ for $2 \mathrm{hr}$ in the presence of $10 \%$ human plasma. DNA was analyzed as described in the legend to Fig. 6 . Right abscissa: Percent toxicity was determined by trypan blue exclusion. Reprinted from Frenkel and Chrzan (19).

One of the major functions of PMNs is to generate active oxygen species in order to combat infections (23-25); however, these oxygen species are known to cause extensive damage to the neighboring tissues, particularly when formed in excessively large amounts or in the absence of the natural stimuli such as bacteria or other particles Such conditions occur during wounding and inflammation. Both cause vasodilation that leads to infiltration of PMNs and diffusion of plasma to the affected areas (23), and both are known for their co-carcinogenic effects (55-57). It has been shown that catalase prevents cellular injury caused by $\mathrm{H}_{2} \mathrm{O}_{2}$ derived from TPA-activated PMNs $(58,59)$ and that mice with low levels of catalase have an increased incidence of duodenal cancer $(60)$. We recently have found that catalase also inhibits formation of HMdU and dTG in DNA exposed to TPA-stimulated PMNs (19). Therefore, generation of $\mathrm{H}_{2} \mathrm{O}_{2}$ by stimulated PMNs in the inflamed or wounded areas, and a consequent formation of oxidized bases in the cellular DNA may be responsible for those co-carcinogenic effects.

\section{Benzo[a]pyrene-Induced Formation of $\mathrm{H}_{2} \mathrm{O}_{2}$}

It is quite well accepted that complete carcinogens such as benzo[a]pyrene (BaP) exert their initiating activity by forming adducts with some bases in DNA after being metabolized to the oxygenated intermediates (61-63), but it is not certain what constitutes their promoting activity. It has been suggested that, similar to tumor promoters, they also induce formation of active oxygen species, particularly since antioxidants reduce the carcino- 
genic effects of $\mathrm{BaP}(64-66)$. It is not established as yet by what mechanism and which of the species may be involved. The suggestion was made that $\mathrm{BaP}$ may also activate phagocytic cells in a manner similar to that of tumor promoters (65). We find that this is not the case, as neither BaP nor 7,12-dimethylbenz[a]anthracene (DMBA) cause activation of $\mathrm{PMNs}$ as measured by $\mathrm{H}_{2} \mathrm{O}_{2}$ formation when used at concentrations between $1 \mathrm{pM}$ and $1 \mathrm{mM}$ (unpublished data). It is then apparent that although active oxygen species can oxidize 7,8-BaP diol (proximate carcinogenic metabolite of $\mathrm{BaP}$ to 7,8-diol-9,10-epoxide (ultimate carcinogenic form) (67), the parent hydrocarbon itself cannot stimulate PMNs to produce those active oxygen species.

Since $\mathrm{BaP}$ is actively metabolized by rat liver microsomes and forms numerous oxidized intermediates (68), we decided to look for the formation of $\mathrm{H}_{2} \mathrm{O}_{2}$ as a byproduct of that process. We found that $\mathrm{H}_{2} \mathrm{O}_{2}$ is indeed formed by microsomes obtained from 3-methylcholanthrene (3MC)-induced Fischer 344 (F344) rats (69). $\mathrm{H}_{2} \mathrm{O}_{2}$ is generated in linearly increasing amounts with an increased dose of $\mathrm{BaP}$, up to near $10 \mu \mathrm{M} \mathrm{H}_{2} \mathrm{O}_{2}$ with $0.5 \mathrm{mM}$ $\mathrm{BaP}$. What is also interesting and potentially important is the fact that pyrene, a noncarcinogenic parent of $\mathrm{BaP}$, does not cause formation of $\mathrm{H}_{2} \mathrm{O}_{2}$. Microsomes obtained from 3MC-induced Sprague-Dawley (SD) rats respond in a similar manner to $\mathrm{BaP}$ treatment and produce comparable amounts of $\mathrm{H}_{2} \mathrm{O}_{2}$. Microsomes of uninduced rats of both strains show the same levels of $\mathrm{H}_{2} \mathrm{O}_{2}$ formation in response to the same concentrations of $\mathrm{BaP}$.

It previously was shown by Lesko and Lorentzen (66) that $\mathrm{H}_{2} \mathrm{O}_{2}$ can be generated during interconversion of $\mathrm{BaP}$ diol and dione when catalyzed by NADH dehydrogenase. Our results show that $\mathrm{P}-450$ reductase activity is about the same in both strains of rats regardless of whether they were preinduced with $3 \mathrm{MC}$ or not, which is in agreement with the findings of others (70). Thus, it is not unexpected that the levels of $\mathrm{H}_{2} \mathrm{O}_{2}$ produced are also similar. Since $\mathrm{H}_{2} \mathrm{O}_{2}$ can cause oxidative DNA damage in the presence of iron ions (43), we next examined DNA coincubated with $\mathrm{BaP}$ treated microsomes for the presence of HMdU and dTG (69).

\section{BaP-Induced HMdU Formation by Microsomes}

It previously was estimated that the oxidative damage to the DNA of BaP-treated cells is about 20 -fold higher than formation of adducts with DNA bases (65). Recently, it was found that thymine glycol is a part of that oxidative damage (71). That formation of oxidized bases may be a more general result of treatment with complete carcinogens is shown by the presence of thymine glycol in the DNA of cells incubated with $N$-hydroxy-2-naphthylamine (71) and of 8-hydroxyguanine in cells treated with 4-nitroquinoline- $N$-oxide (72). In addition, thymine glycol is found in cells that are subjected to UV radiation (71), whereas thymine glycol, 5-hydroxymethyluracil, and 8-hydroxyguanine are present in ionizing radiationtreated cells $(40,73-77)$.

We find that incubation of microsomes obtained from 3MC-induced rats with $\mathrm{BaP}$ causes an increase in $\mathrm{HMdU}$ formation as compared to DNA incubated in the absence of $\mathrm{BaP}$ (Table 3). Amounts of HMdU formed decreased significantly when catalase was present in the incubation mixture containing $\mathrm{BaP}$ to levels well below those formed in the absence of the hydrocarbon. This last finding proves that $\mathrm{H}_{2} \mathrm{O}_{2}$ is necessary for the formation of $\mathrm{HMdU}$ in coincubated DNA. As Table 3 shows, even in the absence of $\mathrm{BaP}$ there is a substantial amount of $\mathrm{HMdU}$ formed in DNA. $\mathrm{H}_{2} \mathrm{O}_{2}$ is also formed, although at an order of magnitude lower than in the presence of $\mathrm{BaP}$. This points to the normal processes of microsomes as being responsible for the background oxidative damage. These findings are in agreement with those of Totter (78), who postulated that oxidative damage caused by normal oxygen metabolism is responsible for the occurrence of spontaneous cancers. He further suggested that these types of cancer are the result of the same primary DNA defects as those formed by ionizing radiation. As we know, oxidized DNA bases such as HMdU and dTG formed in DNA by intraor intercellularly generated active oxygen species $(19,34,42,43,71)$ are also formed through the action of ionizing radiation $(40,72-76,79)$.

Our data show that there is at least an order of magnitude more HMdU formed in DNA by BaP-treated F344 than by SD microsomes. Even in the absence of the hydrocarbon, F344 microsomes were that much more effective. These results are in apparent contrast with formation of $\mathrm{H}_{2} \mathrm{O}_{2}$ and the levels of $\mathrm{P}-450$ reductase which were the same for both strains. It is possible that the differences in HMdU formation by microsomes of these strains are due to the different levels of cytochrome P-450 and in the pattern of $\mathrm{BaP}$ metabolism. Also, differing interactions may occur within microsomes of these two strains that compete with DNA for $\mathrm{H}_{2} \mathrm{O}_{2}$. In addition, the availability of iron ions and $\cdot \mathrm{O}_{\overline{2}}^{-}$may also play a role since in order to be mobilized from ferritin, $\mathrm{Fe}^{3+}$ must be reduced to $\mathrm{Fe}^{2+}(80)$ in which form it can catalyze reduction of $\mathrm{H}_{2} \mathrm{O}_{2}$ to $\cdot \mathrm{OH}$, the actual DNA damaging species. In addition to HMdU, dTG is also formed; however, it does not consistently increase by the treatment of microsomes with $\mathrm{BaP}$. This could be due to the fact that dTG is not only formed by $\mathrm{H}_{2} \mathrm{O}_{2}$ in the presence of $\mathrm{Fe}^{2+}$, but also can

Table 3. Number of HMdU per $10^{4}$ thymidine residues formed in DNA incubated with rat liver microsomes in the absence and presence of $\mathrm{BaP}^{\mathrm{a}}$

\begin{tabular}{cccc}
\hline Rat strain & Control & BaP & $\begin{array}{c}\text { BaP }+ \\
\text { catalase }\end{array}$ \\
\hline Sprague-Dawley & 0.5 & 3.1 & ND $^{\mathrm{b}}$ \\
Fischer 344 & $16.1( \pm 9.0)^{\mathrm{c}}$ & $40.6( \pm 5.9)$ & 5.4 \\
\hline
\end{tabular}

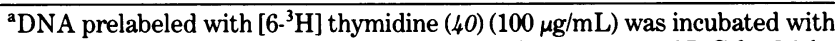
microsomes $(115 \mu \mathrm{g} / \mathrm{mL})$ and NADPH regenerating system at $37^{\circ} \mathrm{C}$ for $2.5 \mathrm{hr}$ in the absence (controls) or presence of $1 \mathrm{mM} \mathrm{BaP}$ (samples). DNA was purified and analyzed for the presence of $\mathrm{HMdU}$ as described in the legend to Fig. 5 (69).

${ }^{\mathrm{b}} \mathrm{ND}$, not determined.

${ }^{\mathrm{C}}$ Mean value $\pm \mathrm{SD}$. 
be degraded under the same conditions (43), and our assay measures only intact dTG.

\section{Conclusions}

Two questions were raised in the "Introduction." The answer to the first question is that formation of oxidized bases in DNA and/or their degradation products most likely are responsible for the first-stage promotional event(s). The answer to the second question is that processes that lead to the formation of active oxygen species in the amounts exceeding the antioxidant capacity of the cells are probably responsible for the formation of the oxidative DNA damage. We show that tumor promoters in vitro can activate PMNs to varying degrees depending on their potency as the in vivo first-stage tumor promoters and, as a result, varying amounts of $\mathrm{H}_{2} \mathrm{O}_{2}$ are generated that correlate with those potencies. Consequently, oxidized bases such as HMdU and dTG are formed in coincubated DNA, the levels of which again correlate with the first-stage promotion. In addition, we show that a complete carcinogen such as $\mathrm{BaP}$, which requires oxidative metabolism for its tumorigenic activity, is capable of producing oxidative DNA base modification. Inhibition of that modification by catalase implicates $\mathrm{H}_{2} \mathrm{O}_{2}$ as a mediator of such damage. The inability of pyrene, a noncarcinogenic (81) congener of $\mathrm{BaP}$, to induce formation of $\mathrm{H}_{2} \mathrm{O}_{2}$ strengthens the hypothesis that active oxygen species generated by carcinogens are involved in the carcinogenic process(es). The ability of $\mathrm{BaP}$ to cause formation of HMdU and dTG, of an aromatic amine to induce formation of dTG, and of 4-nitroquinoline- $N$-oxide to cause formation of 8-hydroxy-2'-deoxyguanosine, all suggest that carcinogen induced processes generating active oxygen species are responsible for the first-stage promoting activity of the complete carcinogens.

The author thanks K. Chrzan for his excellent technical assistance. This investigation was supported in part by PHS grant CA 37858, awarded by the National Cancer Institute, DHHS, and Center grants CA 13343 and ES 00260 .

\section{REFERENCES}

1. Philips, D. H., Grover, P. L., and Sims, P. A quantitative determination of the covalent binding of a series of polycyclic aromatic hydrocarbons to DNA in mouse skin. Int. J. Cancer 23: 201-208 (1979).

2. Lutz, W. K. In vivo covalent binding of organic chemicals to DNA as a quantitative indicator in the process of chemical carcinogenesis. Mutat. Res. 65: 289-356 (1979).

3. Miller, E. C., and Miller, J. A. Searches for ultimate chemical carcinogens and their reactions with cellular macromolecules. Cancer 47: 2327-2345 (1981).

4. Bigger, C. A. H., Sawicki, J. T., Blake, D. M., Raymond, L. G., and Dipple, A. Products of binding of 7,12-dimethylbenz(a)anthracene to DNA in mouse skin. Cancer Res. 43: 5647-5651 (1983).

5. DiGiovanni, J., Sawyer, T. W., and Fisher, E. P. Correlation between formation of a specific hydrocarbon-deoxyribonucleoside adduct and tumor-initiating activity of 7,12-dimethylbenz(a)anthracene and its 9- and 10-monofluoroderivatives in mice. Cancer Res. 46: 4336-4341 (1986).
6. Boutwell, R. K. Some biological aspects of skin carcinogenesis. Prog. Exp. Tumor Res. 4: 207-250 (1964).

7. Slaga, T. J., Fisher, S. M., Nelson, K., and Gleason, G. L. Studies on the mechanism of skin tumor promotion: Evidence for several stages of promotion. Proc. Natl. Acad. Sci. (U.S.) 77: 3659-3663 (1980).

8. Fürstenberger, G., Berry, D. L., Sorg, B., and Marks, F. Skin tumor promotion by phorbol esters is a two-stage process. Proc. Natl. Acad. Sci. (U.S.) 78: 7722-7726 (1981).

9. Fürstenberger, G., Sorg, B., and Marks, F. Tumor promotion by phorbolesters in skin: Evidence for a memory effect. Science 220: 89-91 (1983).

10. Kinzel, V., Fürstenberger, G., Loehrke, H., and Marks, F. Threestage tumorigenesis in mouse skin: DNA synthesis as a prerequisite for the conversion stage induced by TPA prior to initiation. Carcinogenesis 7: 779-782 (1986).

11. O'Connell, J. F., Klein-Szanto, A. J. P., DiGiovanni, D. M., Fries, J. W., and Slaga, T. J. Enhanced malignant progression of mouse skin tumors by the free-radical generator benzoyl peroxide. Cancer Res. 46: 2863-2865 (1986).

12. Slaga, T. J., Fisher, S. M., Weeks, C. E., Nelson, K., Mamrack, M., and Klein-Szanto, A. J. P. Specificity and mechanism(s) of promoter inhibitors in multistage promotion. In: Carcinogenesis, Vol. 7 (E. Hecker, W. Kuntz, N.E. Fusenig, F. Marks, and H. W. Thielmann, Eds), Raven Press, New York, 1982, pp. 19-34.

13. Birnboim, H. C. Importance of DNA strand-break damage in tumor promotion. In: Radioprotectors and Anticarcinogens ( $0 . \mathrm{F}$. Nygaard and M. G. Simic, Eds.), Academic Press, New York, 1983, pp. 539-556.

14. Dutton, D. R., and Bowden, G. T. Indirect induction of a clastogenic effect in epidermal cells by a tumor promoter. Carcinogenesis 6 : 1279-1284 (1985).

15. Lewis, J. G., and Adams, D. O. Induction of 5,6-ring saturated thymine bases in NIH-3T3 cells by phorbol ester-stimulated macrophages: Role of reactive oxygen intermediates. Cancer Res. 45: 1270-1275 (1985).

16. Snyder, R. D. An examination of the DNA damaging and repair inhibitory capacity of phorbol myristate acetate in human diploid fibroblasts. Carcinogenesis 6: 1667-1670 (1985).

17. Floyd, R. A., Watson, J. J., Harris, J., West, M., and Wong, P. K. Formation of 8-hydroxydeoxyguanosine, hydroxyl free radical adduct of DNA in granulocytes exposed to the tumor promoter, tetradecanoylphorbolacetate. Biochem. Biophys. Res. Commun. 137: 841-846 (1986).

18. Takasu, N., Sato, S., Yamada, T., and Shimizu, Y. Epidermal growth factor (EGF) and tumor promoter 12-0-tetradecanoylphorbol-13acetate (TPA) stimulate PG synthesis and thymidine incorporation. Biochem. Biophys. Res. Commun. 143: 880-884 (1987).

19. Frenkel, K., and Chrzan, K. Radiation-like modification of DNA and $\mathrm{H}_{2} \mathrm{O}_{2}$ formation by activated human polymorphonuclear leukocytes (PMNs) In: Anticarcinogenesis and Radiation Protection (P. Cerutti, O. Nygaard, and M. Simic, Eds.), Plenum Publishing, New York, 1987, pp. 97-102.

20. Nathan, C. F., and Root, R. K. Hydrogen peroxide release from mouse peritoneal macrophages. J. Exp. Med. 146: 1648-1662 (1977).

21. Pick, E., and Keisari, Y. Superoxide anion and hydrogen peroxide production by chemically elicited peritoneal macrophagesinduction by multiple nonphagocytic stimuli. Cell. Immunol. 59: 301-318 (1981).

22. Goldstein, B. D., Witz, G., Amoruso, M., Stone, D. S., and Troll, W. Stimulation of human polymorphonuclear leukocyte superoxide anion radical production by tumor promoters. Cancer Lett. 11: 257-262 (1981).

23. Fantone, J. C., and Ward, P. A. Role of oxygen-derived free radicals and metabolites in leukocyte-dependent inflammatory reactions. Am. J. Pathol. 107: 397-418 (1982).

24. Badwey, J. A., and Karnovsky, M. L. Active oxygen species and the functions of phagocytic leukocytes. Annu. Rev. Biochem. 49: 695-726 (1980).

25. Klebanoff, S. J. Oxygen metabolism and the toxic properties of phagocytes. Ann. Intern. Med. 93: 480-489 (1980).

26. Fridovich, I. The biology of oxygen radicals. Science 201: 875-880 (1978). 
27. de Mello-Filho, A. C., and Meneghini, R. Protection of mammalian cells by o-phenanthroline from lethal and DNA-damaging effects produced by active oxygen species. Biochim. Biophys. Acta 847: 82-89 (1985).

28. Cadet, J., and Teoule, R. Comparative study of oxidation of nucleic acid components by hydroxyl radicals, singlet oxygen and superoxide anion radicals. Photochem. Photobiol. 28: 661-667 (1978).

29. Larramendy, M., de Mello-Filho, A. C., Leme-Martins, E. A., and Meneghini, R. Iron-mediated induction of sister-chromatid exchanges by hydrogen peroxide and superoxide anion. Mutat. Res. 178: 57-63 (1987).

30. Aust, S. D., Morehouse, L. A., and Thomas, C. E. Role of metals in oxygen radical reactions. J. Free Rad. Biol. Med. 1: 3-25 (1985).

31. Halliwell, B., and Gutteridge, J. M. Oxygen free radicals and iron in relation to biology and medicine: Some problems and concepts. Arch. Biochem. Biophys. 246: 501-514 (1986).

32. Kano, S., Iizuka, T., Ishimura, Y., Fujiki, H., and Sugimura, T. Stimulation of superoxide anion formation by the non-TPA type tumor promoters palytoxin and thapsigargin in procine and human neutrophils. Biochem. Biophys. Res. Commun. 143: 672-677 (1987).

33. Troll, W., Witz, G., Goldstein, B., Stone, D., and Sugimura, T. The role of free oxygen radicals in tumor promotion and carcinogenesis. In: Carcinogenesis, Vol. 7 (E. Hecker, W. Kuntz, N. E. Fusenig, F. Marks, and H. W. Thielmann, Eds), Raven Press, New York, 1982, pp. 593-597.

34. Frenkel, $\mathrm{K}$., and Chrzan, $\mathrm{K} . \mathrm{H}_{2} \mathrm{O}_{2}$ formation and DNA base modification by tumor promoter-activated polymorphonuclear leukocytes. Carcinogenesis 8: 455-460 (1987).

35. Saito, H., and Tomioka, H. Enhanced hydrogen peroxide release from macrophages stimulated with streptococcal preparation OK-432. Infect. Immunity 26: 779-782 (1979).

36. Fischer, S. M., Hardin, L., Klein-Szanto, A., and Slaga, T. Retinoylphorbol-acetate is a complete skin tumor promoter in SENCAR mice. Cancer Res. 27: 323-327 (1985).

37. Frenkel, K., Chrzan, K., Ryan, C. A., Wiesner, R., and Troll, W. Chymotrypsin-specific protease inhibitors decrease $\mathrm{H}_{2} \mathrm{O}_{2}$ formation by activated human polymorphonuclear leukocytes. Carcinogenesis 8: 1207-1212 (1987).

38. Wayner, D. D. M., Burton, G. W., Ingold, K. U., Barclay, L. R. C., and Locke, $\mathrm{S}$. The relative contributions of vitamin $\mathrm{E}$, urate, ascorbate and proteins to the total peroxyl radical-trapping antioxidant activity of human blood plasma. Biochim. Biophys. Acta 924: 408-419 (1987).

39. Maddipati, K. R., Gasparski, C., and Marrnett, L. J. Characterization of the hydroperoxide-reducing activity of human plasma. Arch. Biochem. Biophys. 254: 9-17 (1987).

40. Frenkel, K., Cummings, A., Solomon, J., Cadet, J., Steinberg, J. J., and Teebor, G. W. Quantitative determination of the 5 (hydroxymethyl)uracil moiety in the DNA of $\gamma$-irradiated cells. Biochemistry 24: 4527-4533 (1985).

41. Scholes, G. Radiation effects on DNA. Br. J. Radiol. 56: 221-231 (1983).

42. Troll, W., Frenkel, K., and Teebor, G. W. Free oxygen radicals: Necessary contributors to tumor promotion and cocarcinogenesis. In: Cellular Interactions by Environmental Tumor Promoters (H. Fujiki, E. Hecker, R. E. Moore, T. Sugimura, and I. B. Weinstein, Eds.), Japan Scientific Societies Press, Tokyo, 1984, pp. 207-218.

43. Frenkel, K., Chrzan, K., Troll, W., Teebor, G. W., and Steinberg, J. J. Radiation-like modification of bases in DNA exposed to tumor promoter-activated polymorphonuclear leukocytes. Cancer Res. 46: 5533-5540 (1986).

44. Cohen, A. M., Aberdroth, R. E., and Hochstein, P. Inhibition of free radical-induced DNA damage by uric acid. FEBS Lett. 174: $147-150$ (1984).

45. Waschke, S., Reefschlager, J., Barwolff, D., and Langen, P. 5-Hydroxymethyl-2'-deoxyuridine, a normal DNA constituent in certain Bacillus subtilis phages is cytostatic for mammalian cells. Nature 225: 629-630 (1975).

46. Meldrum, J.B., Gupta, V. S., Lowes, N. R., Paterson, A. R. P. Toxicologic and antitumor studies on 5-hydroxymethyldeoxyuridine. Toxicol. Appl. Pharmacol. 79: 423-435 (1985).

47. Kahilainen, L. I., Bergstrom, D. E., and Vilpo, J. A. 5-Hydroxymethyl-2'-deoxyuridine, cytotoxicity and DNA incorpo- ration studied by using a novel $\left[2-{ }^{14} \mathrm{C}\right]$ derivative with normal and leukemic human hematopoietic cells. Acta Chem. Scand. B 39: 477-484 (1985).

48. Kaufman, E. R. Biochemical analysis of toxic effects of 5-hydroxymethyl-2'-deoxyuridine in mammalian cells. Somat. Cell Mol. Genet. 12: 501-512 (1986).

49. Shirnamé-Moré, L., Rossman, T. G., Troll, W., Teebor, G. W., and Frenkel, K. Genetic effects of 5-hydroxymethyl-2'-deoxyuridine, a product of ionizing radiation. Mutat. Res. 178: 177-186 (1987).

50. Rouet, P., and Essigman, J. M. Possible role for thymine glycol in the selective inhibition of DNA synthesis on oxidized DNA templates. Cancer Res. 45: 6113-6118 (1985).

51. Ide, H., Kow, Y. W., and Wallace, S. S. Thymine glycol and urea residues in $\mathrm{M} 13$ template constitute replicative blocks in vitro. Nucleic Acids Res. 13: 8035-8052 (1985).

52. Cadet, J., and Teoule, R. Radiolyse $\gamma$ de la thymidine en solution aqueuse aeree. II. Characterization des produits stables. Bull. Soc. Chim. Fr. 3-4: 885-890 (1975).

53. Teoule, R., Bert, C., and Bonicel, A. Thymine fragment damage retained in the DNA polynucleotide chain after irradition in aerated solutions. II. Radiat. Res. 72: 190-200 (1977).

54. Thomas, E. L. Myeloperoxidase, hydrogen peroxide, chloride antimicrobial system: Nitrogen-chlorine derivatives of bacterial components in bacteriocidal action against Escherichia coli. Infect. Immunity 23: 522-531 (1979).

55. Dunham, L. J. Cancer in the man at a site of prior benign lesion of skin or mucous membrane: A review. Cancer Res. 32: 1359-1374 (1972).

56. Dolberg, D. S., Holligsworth, R., Hertle, M., and Bissel, M. J. Wounding and its role in RSV-mediated tumor formation. Science 230: 676-678 (1985).

57. Chester, J. F., Gaissert, H. A., Ross, J. S., Malt, R. A., and Weitzman, S. A. Augmentation of 1,2-dimethylhydrazine-induced colon cancer by experimental colitis in mice: role of dietary vitamin $\mathrm{E}$. J. Natl. Cancer Inst. 76: 939-941 (1986).

58. Simon, R. H., Scoggin, C. H., and Patterson, D. Hydrogen peroxide causes the fatal injury to human fibroblasts exposed to oxygen radicals. J. Biol. Chem. 256: 7181-7186 (1981).

59. Dobrina, A., and Patriarca, P. Neutrophil-endothelial cell interaction. Evidence for and mechanisms of the self-protection of bovine microvascular endothelial cells from hydrogen peroxide-induced oxidative stress. J. Clin. Invest. 78: 462-471 (1986).

60. Ito, A., Watanabe, H., Naito, M., Naito, Y., Kawashima, K. Correlation between induction of duodenal tumor by hydrogen peroxide and catalase activity in mice. Gann 75: 17-21 (1984).

61. Jeffrey, A. M., Weinstein, I. B., Jennette, K.W., Grzeskowiak, K., Nakanishi, K., Autrup, H., and Harris, C. Structures of benzo(a)pyrene nucleic acid adducts formed in human and bovine bronchial explants. Nature 269: 348-350 (1977).

62. Meehan, T., Straub, K., and Calvin, M. Benzo(a)pyrene diol epoxide covalently binds to deoxyguanosine and deoxyandenosine in DNA. Nature 269: 725-727 (1977).

63. Feldman, G., Ramsen, J., Shinohara, K., and Cerutti, P. Excisability and persistence of benzo(a)pyrene DNA adducts in epithelial human lung cells. Nature 274: 796-798 (1978).

64. Wattenburg, L. W. Inhibition of chemical carcinogenesis by antioxidants. In: Carcinogenesis, Vol. 5, Modifiers of Chemical Carcinogenesis (T. J. Slaga, Ed.), Raven Press, New York, 1980, pp. 85-98.

65. Ide, M. L., Kaneko, M., and Cerutti, P. A. Benzo(a)pyrene and ascorbate- $\mathrm{CuSO}_{4}$ induce DNA damage in human cells by indirect action. In: Protective Agents in Cancer (D. C. H. McBrien, and T. F. Slater, Eds.), Academic Press, New York, 1983, pp. 125-140.

66. Lesko, S. A., and Lorentzen, R. J. Benzo(a)pyrene dione-benzo(a)pyrene diol oxidation-reduction couples; involvement in DNA damage, cellular toxicity, and carcinogenesis. J. Toxicol. Environ. Health 16: 679-691 (1985).

67. Dix, T. A., and Marnett, L. J. Metabolism of polycyclic aromatic hydrocarbon derivatives to ultimate carcinogens during lipid peroxidation. Science 221: 77-79 (1983).

68. Capdevila, J., Estabrook, R. W., and Prough, R. A. Differences in the mechanism of NADPH- and cumene hydroperoxide supported reactions of cytochrome P-450. Arch. Biochem. Biophys. 200: 185-195 (1980).

69. Frenkel, K., Donhue, J. M., and Banerjee, S. Benzo(a)pyrene- 
induced oxidative DNA damage: A possible mechanism for promotion by complete carcinogens. In: Oxy-radicals in Molecular Biology and Pathology. UCLA Symposia on Molecular and Cellular Biology, New Series, Vol. 82 (P. Cerutti, I. Fridovich, and J. McCord, Eds.), Alan R. Liss Inc., New York, 1988, pp. 509-524.

70. Dent, J. G., Graichen, M. E., Schnell, S., and Lasker, J. Constitutive and induced hepatic microsomal cytochrome P-450 monooxygenase activities in male Fischer-344 and CD rats. A comparative study. Toxicol. Appl. Pharmacol. 52: 45-53 (1980).

71. Leadon, S. A. Production of thymine glycols in DNA by radiation and chemical carcinogens as detected by a monoclonal antibody. Br. J. Cancer 55 (Suppl. 8): 113-117 (1987).

72. Kohda, K., Tada, M., Kasai, H., Nishimura, S., and Kawazoe, Y. Formation of 8-hydroxyguanine residues in cellular DNA exposed to the carcinogen 4-nitroquinoline 1-oxide. Biochem. Biophys. Res. Commun. 139: 626-632 (1986).

73. Cerutti, P. A. Base damage induced by ionizing radiation. Photochem. Photobiol. Nucleic Acids 2: 375-401 (1976).

74. Frenkel, K., Goldstein, M. S., and Teebor, G. W. Identification of the cis-thymine glycol moiety in chemically oxidized and $\gamma$-irradiated deoxyribonucleic acid by high-pressure liquid chromatography. Biochemistry 20: 7566-7571 (1981).

75. Teebor, G. W., Frenkel, K., and Goldstein, M. Ionizing radiation and tritium transmutation both cause formation of 5-hydroxymethyl2'-deoxyuridine in cellular DNA. Proc. INatl. Acad. Sci. (U.S.) 81: 318-321 (1984).
76. Frenkel, K., Cummings, A., and Teebor, G. W. 5-Hydroxymethyl uracil: A product of ionizing radiation and tritium transmutation formed in DNA. In: Radiation Carcinogenesis and DNA Alterations (F. J. Burns, A. C. Upton, and G. Sillini, Eds.), Plenum Publishing Corp., New York, 1986, pp. 439-445.

77. Kasai, H., Crain, P. F., Kochino, Y., Nishimura, S., Ootsuyama, A., and Tanooka, H. Formation of 8-hydroxyguanine moiety in cellular DNA by agents producing oxygen radicals and evidence for its repair. Carcinogenesis 7: 1849-1851 (1986).

78. Totter, J. R. Spontaneous cancer and its possible relationship to oxygen metabolism. Proc. Natl. Acad. Sci. (U.S.) 77: 1763-1767 (1980).

79. Teebor, G., Cummings, A., Frenkel, K., Shaw, A., Voituriez, L., and Cadet, J. Quantitative measurement of the diastereoisomers of cis thymidine glycol in gamma-irradiated DNA. Free Rad. Res. Commun. 2: 303-309 (1987).

80. Biemond, P., van Eijk, H. G., Swaak, A. J. G., and Koster, J. F. Iron mobilization from ferritin by superoxide derived from stimulated polymorphonuclear leukocytes. Possible mechanism in inflammation diseases. J. Clin. Invest. 73: 1576-1579 (1984).

81. IARC. Pyrene. In: IARC Monographs on the Evaluation of the Carcinogenic Risk of Chemicals to Humans. Polynuclear Aromatic Compounds, Part 1, Chemical, Environmental and Experimental Data, Vol. 32. International Agency for Research on Cancer, France, 1983, pp. 431-445. 